\title{
Study on the Factors Affecting the Environmental Behaviors of the Community Residents in Leisure Agriculture Tourism Destinations
}

\author{
Xiuzhi Lin \\ School of Management, \\ Fujian Agriculture and Forestry University, \\ Fuzhou 350002, Fujian
}

\begin{abstract}
The environmental behaviors of the community residents, as the demonstrators, supervisors and beneficiaries of the leisure agriculture tourism destinations play an effect on the ecological environment of the leisure agriculture tourism destinations to a certain extent. In this study, the environmental behaviors of the community residents as well as affecting factors were measured through factor analysis, descriptive statistics, correlation analysis and regression analysis by taking Baishawan Ecological Farm Village for example and using 9 environmental behavior indexes and 20 affecting factor indexes. The results showed that the environmental values and knowledge had a remarkable effect on the environmental propaganda and education behaviors and citizenship behaviors; a sense of responsibility for environment, the environmental management level, and the external environment standards had a significant effect on the environmental management behaviors; other factors played a relatively small effect on the three major environmental behaviors. Finally, the enlightenment to optimizing the environmental behaviors of the community residents in Baishawan Ecological Farm Village is raised.
\end{abstract}

Keywords-Leisure Agriculture; Community Residents; Environmental Behaviors; Affecting Factors

\author{
Xiujuan Huang \\ School of Management, \\ Fujian Agriculture and Forestry University, \\ Fuzhou 350002, Fujian
}

\section{Introduction}

Leisure agriculture tourism destinations have attracted many tourists because of fresh natural environment and unique regional cultures. There are many results of studying the environmental behaviors of residences at home and abroad, but most of them focused on the daily environmental behaviors of urban residences and peasants [1-9]. In the study of the factors affecting the environmental behaviors, the affecting factor focused by the academic circles at the earliest was environmental attitude [10]. The study of the factors affecting the environmental behaviors has been gradually expanded to the intrinsic factors such as the sense of responsibility for environment, sensitivity to environment, environmental knowledge and environmental values, and the extrinsic factors such as the demographic situation, government policies, social norms, social structure, and industrial conditions [11-15]. Seen from the present studies, there are many studies on the one or several affecting factors; systematic studies are few. Therefore, the environmental behaviors of different groups are necessarily studied in a specialized way, in order to improve the environmental behavior study system.

\section{Study design}

\subsection{The selection of the study area}

As a "demonstration pilot project of leisure agriculture in Fujian province", "three-star rural 
tourism business unit in Fujian province", and "typical destination of the national leisure agriculture and rural tourism in Minhou County", Baishawan Ecological Farm Village has attracted the masses of tourists because of its farming culture and leisure entertainment projects such as flowers and plants sightseeing, fruit picking, plant maze, delicious rural food, horse riding and archery, and dragon and lion dance. Therefore, Baishawan Ecological Farm Village, chosen as a case, is typical and representative.

\subsection{Questionnaire design and data collection}

The questionnaire used in this study included five parts: (1) individuality and cognitive factors, including 14 items; (2) situational factors, including 6 items; (3) environmental behaviors, including 9 items; (4) the community residence information, including 6 items. For parts I and II, Liktert Scale was applied: 1-"strongly disagree"; 2-"disagree"; 3-"neutral"; 4-"agree"; 5"strongly agree". For part III, Liktert Scale was applied: 1-"never"; 2-preciously little; 3 "little"; 4-"sometimes"; 5-"always".

A total of 150 questionnaires were issued, of which 139 were returned. But 127 returned questionnaires were valid. The Cornbach's $\alpha$ coefficient of the data was calculated with SPSS16.0 software, thus the total reliability of the scale was $\alpha=0.819$; the reliability of the individuality and cognitive factors scale wasa $=0.775$; the reliability of the situational factors scale was $\alpha=0.744$; the reliability of the environment behavior scale was $\alpha=0.716$.

\section{Empirical results and data analysis}

\subsection{Factor analysis and descriptive statistics analysis}

KMO and Bartlett's spherical test was made for the individuality and cognitive factors scale, the situational factors scale, and the environment behavior scale. After the test, the KMO values of the three scales were $0.759,0.718$, and 0.693 respectively, and passed the Bartlett's spherical test $($ Sig $=0.000)$.

The principal component extraction method was used for the factor analysis, and the extracted common factors were rotated with the oblique rotation method, as shown in table 1. Two common factors were extracted from the situational factors scale, and the cumulative variance contribution rate was $57.506 \%$, as shown in table 2 . Three common factors were extracted from the environmental behavior scale, and the cumulative variance contribution rate was $60.725 \%$, as shown in table 3 .

Seen from table 1, the studied objects' sense of responsibility for environment remained to be further improved; the studied objects had correct environmental values, but were weak in the environmental knowledge. 
Table 1: Individuality and knowledge factors analysis and descriptive statistical analysis

\begin{tabular}{|c|c|c|c|c|c|}
\hline Factor & Question & MV & SD & $\begin{array}{l}\text { Factor } \\
\text { loading cc }\end{array}$ & $\begin{array}{l}\text { Variance } \\
\text { ntributes }(\%)\end{array}$ \\
\hline \multirow{3}{*}{ Environmental values } & $\begin{array}{l}\text { A1: Leisure agriculture tourism } \\
\text { environment is vulnerable to damage } \\
\text { and needs protection }\end{array}$ & 3.80 & 0.727 & 0.769 & \multirow{3}{*}{7.784} \\
\hline & $\begin{array}{l}\text { A2: Leisure agriculture tourism } \\
\text { environment can be protected as long } \\
\text { as the development is moderate }\end{array}$ & 3.06 & 0.780 & 0.705 & \\
\hline & $\begin{array}{l}\text { A3: The coordination of leisure } \\
\text { agriculture project construction with } \\
\text { the surroundings is necessarily } \\
\text { considered }\end{array}$ & 4.56 & 0.498 & 0.707 & \\
\hline \multirow{3}{*}{$\begin{array}{l}\text { Sense of responsibility } \\
\text { for environment }\end{array}$} & $\begin{array}{l}\text { A4: The improvement and solution } \\
\text { by experts and leadership to the } \\
\text { leisure agriculture environment } \\
\text { problems can play a key role }\end{array}$ & 3.86 & 0.626 & 0.869 & \multirow{3}{*}{12.090} \\
\hline & $\begin{array}{l}\text { A5: Human can take measures to } \\
\text { actively protect leisure agriculture } \\
\text { tourism environment }\end{array}$ & 4.53 & 0.561 & 0.691 & \\
\hline & $\begin{array}{l}\text { A6: Community residents have the } \\
\text { responsibility for protecting leisure } \\
\text { agriculture tourism environment }\end{array}$ & 3.26 & 0.910 & 0.845 & \\
\hline \multirow{3}{*}{$\begin{array}{l}\text { Personal environment } \\
\text { specification }\end{array}$} & $\begin{array}{l}\text { A7: Farming environmental damages } \\
\text { make you feel anxious and anger }\end{array}$ & 3.83 & 0.676 & 0.862 & \multirow{3}{*}{16.412} \\
\hline & $\begin{array}{l}\text { A8: Protecting the farm environment } \\
\text { lets you respected by others }\end{array}$ & 4.49 & 0.602 & 0.736 & \\
\hline & $\begin{array}{l}\text { A9: Destroying the farm } \\
\text { environment harms the personal } \\
\text { image and quality }\end{array}$ & 3.76 & 0.771 & 0.855 & \\
\hline \multirow{5}{*}{$\begin{array}{l}\text { Environmental } \\
\text { knowledge }\end{array}$} & $\begin{array}{l}\text { A10: What behaviors do you know to } \\
\text { damage the farm environment? }\end{array}$ & 3.85 & 0.691 & 0.693 & \multirow{5}{*}{29.741} \\
\hline & $\begin{array}{l}\text { A11: What methods do you know to } \\
\text { improve the farm environment? }\end{array}$ & 3.09 & 0.623 & 0.677 & \\
\hline & $\begin{array}{l}\text { A12: Do you acquire environmental } \\
\text { knowledge from school? }\end{array}$ & 2.98 & 0.527 & 0.798 & \\
\hline & $\begin{array}{l}\text { A13: Do you acquire environment } \\
\text { knowledge from media? }\end{array}$ & 3.87 & 0.706 & 0.750 & \\
\hline & $\begin{array}{l}\text { A14: Do you acquire environmental } \\
\text { knowledge from the environmental } \\
\text { interpretation system? }\end{array}$ & 2.95 & 0.711 & 0.712 & \\
\hline
\end{tabular}

Seen from table 2, the studied objects would be more inclined to take positive environmental behaviors if the environmental management level and the external environment standards and regulations were strengthened. 
Table 2: Situational factors analysis and descriptive statistical analysis

\begin{tabular}{|c|c|c|c|c|c|}
\hline Factor & Question & MV & SD & $\begin{array}{l}\text { Factor } \\
\text { loading }\end{array}$ & $\begin{array}{c}\text { Variance } \\
\text { contributes } \\
(\%)\end{array}$ \\
\hline \multirow[b]{2}{*}{$\begin{array}{l}\text { Environmental } \\
\text { management level }\end{array}$} & $\begin{array}{l}\text { B1: Does the environmental education } \\
\text { from farm workers play a positive } \\
\text { effect on your environment behavior? }\end{array}$ & 4.07 & 0.593 & 0.858 & \multirow[b]{2}{*}{19.964} \\
\hline & $\begin{array}{l}\text { B2: Do you abide by the instructions on } \\
\text { the environmental protection } \\
\text { propaganda materials and } \\
\text { environmental interpretation boards of } \\
\text { the farm village? }\end{array}$ & 3.58 & 0.684 & 0.886 & \\
\hline \multirow{4}{*}{$\begin{array}{l}\text { External } \\
\text { environment } \\
\text { standards and } \\
\text { regulation }\end{array}$} & $\begin{array}{l}\text { B3: Village people are condemned } \\
\text { because of environmental damage }\end{array}$ & 3.88 & 0.498 & 0.603 & \multirow{4}{*}{37.542} \\
\hline & $\begin{array}{l}\text { B4: Farm environmental protection } \\
\text { needs everyone to participate in }\end{array}$ & 4.60 & 0.523 & 0.643 & \\
\hline & $\begin{array}{l}\text { B5: Do you actively protect the village } \\
\text { environment if there is a clear reward } \\
\text { mechanism? }\end{array}$ & 3.29 & 0.536 & 0.717 & \\
\hline & $\begin{array}{l}\text { B6: Do you actively protect the village } \\
\text { environment if there is a clear penalty } \\
\text { mechanism? }\end{array}$ & 4.39 & 0.520 & 0.783 & \\
\hline
\end{tabular}

Seen from table 3, the overall scores of the environmental behavior of the residences in
Baishawan Ecological Farm Village were not very high. 
Table 3: Environmental factors analysis and descriptive statistical analysis

\begin{tabular}{|c|c|c|c|c|c|}
\hline Factor & Question & MV & SD & $\begin{array}{l}\text { Factor } \\
\text { loading }\end{array}$ & $\begin{array}{c}\text { Variance } \\
\text { contributes }(\%) \\
\end{array}$ \\
\hline \multirow{4}{*}{$\begin{array}{l}\text { Environment } \\
\text { management } \\
\text { behavior }\end{array}$} & $\begin{array}{l}\text { C1: You plant organic fruits and } \\
\text { vegetables in the village }\end{array}$ & 3.49 & 0.722 & 0.593 & \multirow{4}{*}{23.176} \\
\hline & $\begin{array}{l}\text { C2: You sell agricultural products in the } \\
\text { village, but do not bark }\end{array}$ & 3.99 & 0.636 & 0.796 & \\
\hline & $\begin{array}{c}\text { C3: The vehicle used by you usually does } \\
\text { not pollute the village }\end{array}$ & 3.31 & 0.684 & 0.755 & \\
\hline & $\begin{array}{l}\text { C4: You put the rubbish in the garbage or } \\
\text { designated collection points }\end{array}$ & 4.38 & 0.518 & 0.625 & \\
\hline \multirow{3}{*}{$\begin{array}{l}\text { Environmental } \\
\text { propaganda and } \\
\text { education behavior }\end{array}$} & $\begin{array}{l}\text { C5: You guide or encourage others to } \\
\text { protect the village environment }\end{array}$ & 3.71 & 0.798 & 0.867 & \multirow{3}{*}{16.640} \\
\hline & C6: You participated in the farm & & & & \\
\hline & $\begin{array}{l}\text { environmental propaganda and education } \\
\text { activities }\end{array}$ & 2.48 & 0.805 & 0.872 & \\
\hline \multirow{3}{*}{$\begin{array}{l}\text { Citizenship } \\
\text { behavior }\end{array}$} & $\begin{array}{l}\text { C7: You donated money to the village or } \\
\text { relevant departments for environmental } \\
\text { protection }\end{array}$ & 2.26 & 0.657 & -0.862 & \multirow{3}{*}{20.909} \\
\hline & $\begin{array}{l}\text { C8: You promoted governmental } \\
\text { departments to solve the village } \\
\text { environmental problems by lobbying, } \\
\text { vote, political campaign and other } \\
\text { political actions }\end{array}$ & 1.48 & 0.547 & -0.662 & \\
\hline & $\begin{array}{l}\text { C9: You complained, accused, or reportec } \\
\text { the village environmental damage events }\end{array}$ & 2.16 & 0.672 & -0.865 & \\
\hline
\end{tabular}

\subsection{Correlation and regression analysis}

All kinds of environmental behavior and affecting factors in the leisure agriculture tourism communities were correlatively analyzed, in order to know well the internal structure and relationship. 
Table 4: The correlation coefficient matrix of various environmental behaviors and affecting factors

$\begin{array}{lllllllll}1 & 2 & 3 & 4 & 5 & 6 & 7 & 8 & 9\end{array}$

\begin{tabular}{|c|c|c|c|c|c|c|c|c|}
\hline $\begin{array}{l}\text { 1. Environmental } \\
\text { management level }\end{array}$ & 1 & & & & & & & \\
\hline $\begin{array}{l}2 . \quad \text { Environmental } \\
\text { propaganda and education } \\
\text { behavior }\end{array}$ & 0.064 & 1 & & & & & & \\
\hline 3. Citizenship behavior & 0.089 & 0.088 & 1 & & & & & \\
\hline 4. Environmental values & 0.125 & $0.191 *$ & $0.667 * *$ & 1 & & & & \\
\hline $\begin{array}{l}\text { 5. Sense of responsibility } \\
\text { for environment }\end{array}$ & $0.485^{* *}$ & 0.121 & 0.017 & 0.079 & 1 & & & \\
\hline $\begin{array}{l}\text { 6. Personal environment } \\
\text { specification }\end{array}$ & 0.101 & 0.012 & 0.023 & 0.040 & 0.114 & 1 & & \\
\hline $\begin{array}{l}\text { 7. Environmental } \\
\text { knowledge }\end{array}$ & 0.150 & 0.136 & $0.602 * *$ & $0.288 * *$ & 0.079 & 0.016 & 1 & \\
\hline $\begin{array}{l}8 . \quad \text { Environmental } \\
\text { management level }\end{array}$ & $0.493 * *$ & 0.033 & 0.027 & 0.006 & $0.222 *$ & 0.018 & 0.097 & 1 \\
\hline $\begin{array}{l}\text { 9. Environment standard } \\
\text { and regulation }\end{array}$ & $0.477 * *$ & 0.049 & 0.083 & 0.068 & $0.468 * *$ & 0.159 & 0.030 & $0.275^{* *}$ \\
\hline
\end{tabular}

Note: $* *$ the significant level $(<0.01)$ (two-tailed test); *-the significant level $(<0.05)$ (two-tailed test)

Linear regression analysis was conducted on all kinds of environmental behaviors using a stepwise regression method. Seen from the standardized regression coefficients, the major effect variables of the environmental management behavior were in turn the environmental management level, the sense of responsibility for environment, and the external environment standard and regulation; the environmental propaganda and education behavior and citizenship behavior were mainly affected by environmental values and environmental knowledge, and their affecting degrees were different. 
Table 5: A regression analysis of environmental management behavior

\begin{tabular}{|c|c|c|c|}
\hline Independent variable & $\begin{array}{l}\text { Standardized } \\
\text { coefficients }\end{array}$ & regression $_{t}$ value & Sig. \\
\hline Environmental management level & 0.362 & 5.099 & 0.000 \\
\hline $\begin{array}{l}\text { Sense of responsibility for } \\
\text { environment }\end{array}$ & 0.292 & 3.783 & 0.000 \\
\hline Environment standard and regulation & 0.240 & 3.066 & 0.003 \\
\hline \multicolumn{4}{|c|}{ Adjusted $\mathrm{R}^{2}=0.420 ; \mathrm{DW}$ value $=1.699 ; \mathrm{F}$ value $=31.436$} \\
\hline
\end{tabular}

Table 6: A regression analysis of environmental propaganda and education behavior

\begin{tabular}{llll}
\hline Independent variable & $\begin{array}{l}\text { Standardized } \\
\text { coefficients }\end{array}$ & regression & \\
\hline Environmental values & 0.250 & $\mathrm{t}$ value & Sig. \\
Environmental knowledge & 0.208 & 2.778 & 0.006 \\
& 2.307 & 0.023
\end{tabular}

Adjusted $\mathrm{R}^{2}=0.461$; DW value $=1.938 ; \mathrm{F}$ value $=35.098$

Table 7: A regression analysis of citizenship behavior

\begin{tabular}{llll}
\hline Independent variable & Standardized regression coefficients & t value & Sig. \\
\hline Environmental values & 0.538 & 9.412 & 0.000 \\
Environmental knowledge & 0.447 & 7.811 & 0.000
\end{tabular}

Adjusted $\mathrm{R}^{2}=0.622 ;$ DW value $=1.894 ; \mathrm{F}$ value $=104.636$

\section{Conclusion}

From the above analysis, a conclusion as follows is drawn up. First, environmental behavior was divided into three types: environmental management behavior, environmental propaganda and education behavior, and citizenship behavior; the affecting factors included the individuality and knowledge factors and situational factors. Second, the environmental behaviors of the residences in Baishawan Ecological Farm Village were mostly focused on the environmental management level; the environmental propaganda and education behavior and citizenship behavior were performed not much, and the overall level remained to be further optimized. Third, environmental values and environmental knowledge played a significant effect on the environmental propaganda and education behavioral and citizenship behavior, but a very common effect on the environmental management behavior.

Therefore, the concrete enlightenment from this study can be summarized from two points. First, the environmental education is promoted through multiple channels and methods, so that the people can set up correct environmental values and are guided to positively treat the environment. Second, it is necessary to give full play to the role of social public opinion and public standards, make a straightforward reward and punishment mechanism, and establish a good platform for supporting and guaranteeing the environmental behaviors of the residences through the constraining force of external factors.

\section{Acknowledgement}

This paper aided financially by the Soft Science Project of the Science and Technology Department of Fujian Province (No.2013R0013). 


\section{References}

[1] Wen-juan GONG, Jun LEI. The Gender Differences in Chinese Urban Residents Environmental Concern and Environmentally Friendly Behaviors [J]. Journal of Hainan University (Humanities and Social Science Edition), 2007, 25 (3): 340-345.

[2] Minghao Tang, Qing Zhou, et al. Survey on the Environmental Attitude and Behavior of Urban Residents [J]. Journal of Xiangtan Normal University (Natural Science Edition), 2009, 31 (1): 149-152.

[3] Qi-yan Wang, Peng Hou. Study on Beijing Urban Residents' Environmental Behavior and Intention [J]. China Population Resources and Environment, 2010, (10): 61-67.

[4] Khalil Kalantari, Hossein Shabanali Fami, Movahed Mohammadi. Investigating Factors Affecting Environmental Behavior of Urban Residents: A Case Study in Tehran City-Iran [J]. American Journal of Environmental Sciences, 2007, 3 (2): 67-74.

[5] Jinhua Chen, Wenqi Yang, et al. Study on the Environment Sustainable Development of the Coastal Wetland Tourism Resources from the Perspective of the Local Residents' Perception [J]. Ecological Economy, 2006, (2): 171-178.

[6] Jun LIANG, Shuofei ZHENG. An Empirical Study on the Community Participation in Rural Tourism Environment System Maintenance - Yujia Village uf Jingxing County Is Taken for example [J]. Journal of Anhui Agricultural Science, 2008, 36 (21): 9232-9232.

[7] Lei Wang, Baoxiang Wei. Analysis on the Factors Affecting the Environmental Protection Intention of Residents in Destinations- Yellow River Stone Forest of Gansu Is Taken for example [J]. Journal of Anhui Agricultural Science, 2010, 38 (16): 8723-8723.
[8] Bo HUANG, Lingfeng ZENG. Study on the Environmental Awareness of Nature Reserve Community Villagers and the Environmental Education Strategies Daming Mountain and Longshan Nature Reserve in Guangxi Are Taken for example [J]. Journal of Guangxi Normal University (Natural Science Edition), 2010, 27 (2): 97-101.

[9] Qiong XIAO. Study on the Cultural Ecological Environment Protection of Tourism Communities under the Background of Urbanization [J]. Urban development research, 2011, 18 (11): 104-109.

[10]Dunlap R. Environmental Sociology: A Personal Perspective on Its First Quarter Century [J].Organization \& Environment, 2002, 15 (1):10-29.

[11]] Kaiser F, Gutscher H. The Proposition of a General Version of the Theory of Planned Behavior: Predicting Ecological Behavior [J].Journal of Applied Social Psychology, 2003, 33 (3): 586-603.

[12] Shizhang XU. Study on the Important Life Experience in the Cultivation of Affecting the Positive Environmental Behaviors in Hualianghuan Group [J]. Journal of Science Education in Taiwan, 2003, 11 (2): 121-139.

[13]Frick J., Kaiser F. G., Wilson M. Environmental Knowledge and Conservation Behavior: Exploring Prevalence and Structure in a Representative Sample [J].Personality and Individual Differences, 2004, (37):1597-1613.

[14]Feng CUI, Yixin XING. A Sociological Study Review of Environmental Behaviors [J]. Journal of Nanjing University of Technology (Social Science Edition), 2012, 11 (2): 5-11.

[15]Holder-Webb L, Cohen J R, Nath L, et al. The Supply of Corporate Social Responsibility Dilosures among US Fimts [J]. Journal of Business Ethics, 2009, (4): 497-527. 